\title{
THE INTERNATIONAL COURT OF JUSTICE AND THE RECOGNITION OF STATES
}

\author{
Gentian Zyberi
}

\section{Introduction}

As Lauterpacht has noted (1947: v), 'there are only very few branches of international law which are of greater, or more persistent, interest and significance for the law of nations than the question of Recognition of States, of Governments and of Belligerency. Yet there is probably no other subject in the field of international relations in which law and politics appear to be more closely interwoven.' Understandably, answers to these questions are of heightened importance and urgency especially during turning historical moments as the aftermath of the Second World War (WW2), or the early 1990s with the dissolution and violent breakup respectively of the Soviet Union and Yugoslavia. While international law addresses different aspects of recognition (Talmon, 2000), this chapter focuses on the contribution of the International Court of Justice (ICJ or Court) to clarifying different legal aspects of the inter-related processes of State creation and recognition. The ICJ is an important international adjudication mechanism, entrusted with settling inter-State disputes and providing legal advice to the United Nations (UN) main organs and other duly authorised organs and special agencies (ICJ Handbook, 2014; Shaw, 2016; Zimmermann, Tomuschat, Oellers-Frahm, and Tams, 2012 (ICJ Statute Commentary); Thirlway, 2016; Kolb, 2013; Hernández, 2014; Zyberi, 2008). The decisions of the Court have contributed to the development of different areas of international law (Tams and Sloan, 2013). The general authority of ICJ's decisions, and the fact noted by Dugard (1987: 126) that the UN has become 'the collective arbiter of statehood through the process of admission and nonrecognition', demonstrate the potentially important institutional role that the ICJ can play within the UN context.

The main contributions of the Court to the issue of creation and recognition of States consist of legal findings clarifying the criteria for admission to UN membership and the role of the General Assembly and the Security Council therein, the emergence of new States through the process of decolonisation, declarations of independence, and conditions for States' access to ICJ's contentious and advisory proceedings. The issue of access to the Court's jurisdiction could arise in the case of withdrawal, suspension as in the case of the former Yugoslavia (Rosenne, 2010), or expulsion of a State from the UN, as well as from the termination of the existence of a State as in the Gabčikovo-Nagymaros Project case between Hungary and Slovakia (Gabčikovo-Nagymaros Project, ICJ Reports 1997, p. 7). While this latter case was about differences that had existed between Hungary and Czechoslovakia concerning the building of a system of dams in the Danube River, the 1993 Special Agreement about bringing the dispute before the Court reached between Hungary and Slovakia recorded that the latter was in this respect the sole successor State of Czechoslovakia. The Court has also settled disputes concerning land and maritime border 
delimitations related to the emergence of new States in Africa and elsewhere (Riziki Majinge, 2012).

First, this chapter places in context the role of an important international adjudication mechanism as the Court in interpreting different legal aspects concerning the process of State recognition. Then, it proceeds to analysing the following issues, namely access to the Court for UN non-member States and differences between contentious cases and advisory proceedings; conditions for admission and membership of States in the UN; State recognition and self-determination in the context of decolonisation, including collective non-recognition of internationally wrongful acts; and, declarations of independence under international law.

\section{The Court and the process of State recognition}

Article 7 of the UN Charter lists the ICJ as one of the six main organs of the UN, alongside the General Assembly and the Security Council. Articles 92-96 contained in Chapter XIV of the UN Charter regulate broadly access to and the place of the ICJ within the UN institutional framework. Article 92 recognizes the Court as the UN's principal judicial organ. Article 35(1) of the ICJ Statute provides that the Court shall be open to the States party to the Statute, and Article 93(1) of the UN Charter provides that all UN Member States are ipso facto parties to the Statute. Article 93(2) regulates access to the Court for non-UN members. Article 94 establishes the obligations of parties to a dispute to comply with the decisions of the Court (Schulte, 2004). Article 95 ensures the States' freedom of choice when it comes to making use of dispute settlement mechanisms. Finally, Article 96 enables the General Assembly and the Security Council to ask the Court for legal advice on any legal matter and other UN organs and specialized agencies to ask for legal advice on matters related to their activities (Aljaghoub, 2006). This provision concerning the ICJ's advisory jurisdiction is further supplemented by Article 65 of the ICJ Statute (Chapter IV on Advisory Opinions). Under Articles 59 and 60 of the ICJ Statute, the Court's judgments are final, without appeal, and binding for the parties to a dispute, whereas its advisory opinions are generally considered as authoritative interpretations of international law.

The basic criteria for statehood are codified in Article 1 of the 1933 Montevideo Convention on the Rights and Duties of States and include 1) a permanent population; 2) a defined territory; 3) a government; and 4) the capacity to enter into relations with other States (Convention on the Rights and Duties of States, 26 December 1933, 165 LNTS 19). These statehood criteria are closely related to the right of peoples to self-determination (Cassese, 1995; Zyberi, 2009; Summers, 2013). The Court has helped clarify certain aspects of achieving statehood and the related interaction among States at the international level (Orakhelashvili, 2015). State recognition is primarily a political act that entails legal consequences. Essentially, the act of recognition mainly involves the individual States concerned. As Dugard has noted (1987: 166), a State enjoys considerable discretion in deciding whether to recognise another State, except where the Security Council has directed States not to recognise an entity as a State. More generally, the UN plays an important role in the recognition of States by certificating the existence of some States through its admission procedure and by denying the existence of others by means of non-recognition (Lauterpacht, 1947; Dugard, 1987: 164; Crawford, 2006: 131-134 and 157-173; Fabry, 2010). However, different interests might be at stake in such cases. Thus, a problem presented itself in the 
South West Africa case, where South Africa exercised authority over South West Africa and its inhabitants contrary to the decisions of the UN Security Council and the General Assembly. As Orakhelashvili has noted (2015: 177), in this case the Court effectively proposed a two-pronged guideline for assessing State conduct: whether the recognition of the relevant act serves the interests of the inhabitants; and whether such recognition permits the illegal occupier to assert such public authority as the occupation purports to generate (Legal Consequences for States of the Continued Presence of South Africa in Namibia (South West Africa) notwithstanding Security Council Resolution 276 (1970), ICJ Reports 1971, pp. 5556, paras. 121-127, especially para. 125). The advisory opinions in South West Africa and the Legal Consequences of the Construction of a Wall in the Occupied Palestinian Territory clarify State obligations with regard to exercise of public authority from an occupation power.

Besides acts of individual recognition between States and collective recognition through a State's admission into the UN, there are several other indicators of the level of recognition of a State at the international level. First, membership in the UN is commonly seen as a marker of universal and full recognition of statehood (Rosennne, 1949; Dugard, 1987). Yet, as Crawford has generally noted (2006: 193) with regard to UN membership, a member State could withdraw or be expelled, a new State might not seek admission. Another important marker of international recognition, especially for a contested State, is to join different regional and international organisations, or the treaty establishing an international court, as the International Criminal Court. Palestine joined the International Criminal Court and the Permanent Court of Arbitration in 2015. Kosovo joined the Permanent Court of Arbitration in 2016. Yet another could be joining or starting legal proceedings before an international court, like the ICJ. Palestine participated in the Legal Consequences of the Construction of a Wall in the Occupied Palestinian Territory (Wall Advisory Opinion) and in September 2018 started a case against the US (Relocation of the United States Embassy to Jerusalem (Palestine v. United States of America)). Kosovo participated in the advisory proceedings in the Accordance with international law of the unilateral declaration of independence in respect of Kosovo (Kosovo Independence Declaration case). Overall, and especially for contested States, membership in international and regional organisations is relevant for getting access to peaceful dispute settlement mechanisms and to global public goods and services. Such participation strengthens their claim to statehood and formalises their engagement with other States in the international arena.

The principle of peaceful settlement of disputes does not require or depend on the mutual recognition of the parties concerned. Moreover, making the settlement of disputes subject to mutual recognition could potentially undermine this general principle of international law, codified in Article 33 of the UN Charter. The ICJ seems to favour the view that statehood and related rights do not depend on mutual recognition by the parties to a dispute (Application of the Convention on the Prevention and Punishment of the Crime of Genocide (Bosnia and Herzegovina v. Serbia and Montenegro), ICJ Reports 1996, p. 595 (Application of the Genocide Convention)). In this case, the Court found that even if for purposes of establishing jurisdiction there was no need to settle the question of what the effects of a situation of non-recognition may be on the contractual ties between parties to a multilateral treaty, even if it were to be assumed that the Genocide Convention did not enter 
into force between the Parties until the signature of the Dayton-Paris Agreement, all the conditions were fulfilled to found the jurisdiction of the Court ratione personae (Application of the Genocide Convention, ICJ Reports 1996, p. 613, para. 26). The condition under Article 34(1) of the ICJ Statute that only States may be parties in cases before the Court is satisfied for all UN member States, but can be subject to controversy in the case of non-member States to the UN, or in case of State succession or other changes while the case is pending. In such situations, it is for the ICJ to decide whether the conditions for access to its jurisdiction have been satisfied.

\subsection{Access to the Court for UN non-member States}

Under Article 93(2) of the UN Charter, even States non-member to the UN may become a party to the ICJ Statute, on conditions to be determined in each case by the General Assembly upon the recommendation of the Security Council (Oellers-Frahm, ICJ Statute Commentary, 2012: 179-185). States that became parties to the Statute of the ICJ before being admitted to the UN include Japan, Liechtenstein, San Marino, Nauru, and Switzerland (Oellers-Frahm, ICJ Statute Commentary, 2012: 183). As Rosenne has noted (2006: 599), perusal of the debates in the Security Council and the General Assembly discloses that, except in the case of Switzerland, the object of repeated discussion was not the conditions, but whether the applicant was a State which should or could become a party to the Statute.

Another potential venue for joining the ICJ Statute is Resolution 9(1946) of the Security Council, whereby a State can become a part of the ICJ Statute by accepting the jurisdiction of the Court, in accordance with the UN Charter and with the terms and subject to the conditions of the Statute and Rules of the Court, and undertaking to comply in good faith with the decision or decisions of the Court and to accept all the obligations of a Member of the United Nations under Article 94 of the Charter. This Resolution relates directly to Article 35(2) of the ICJ Statute, but in contrast to Article 93(2) of the UN Charter, the statehood of an entity coming before the Court is not subject to a preliminary political and binding determination by the General Assembly, upon a recommendation by the Security Council. The ICJ would be able to decide in this case and it remains debatable whether the Court in exercising its depositary functions could or should decide on the statehood issue, or just accept it at face value. Palestine has used this option to join the ICJ, through a declaration sent to the Court in July 2018.

The two possibilities of getting access to the Court for non-UN member States, respectively under Article 93(2) of the UN Charter and under Security Council Resolution 9(1946) and Article 35(2) of the ICJ Statute, are relevant especially when new States come into existence, but do not or cannot join the UN. As Rosenne has noted (2006: 600), three cases have concerned State parties to the ICJ Statute under Article 93(2), namely Nottebohm (Liechtenstein), Interhandel (Switzerland), and Phosphate Lands in Nauru (Nauru). Overall, under the UN Charter articles and subsequent practice, access to the ICJ appears to be open open to territorial entities that have at least some degree of international status.

\subsection{Access to the Court in contentious cases versus advisory proceedings}

While under articles 34 and 35 of the ICJ Statute access to the Court in contentious cases is limited to States, whether members of the UN or not, a more lenient approach is taken by the 
Court with regard to advisory proceedings (Hernández, 2011: 150-151). Under Article 66(2) of the ICJ Statute, the Registrar of the Court shall inform States or international organisations that can provide the Court with relevant information of the possibility to participate in its advisory proceedings. As Zimmermann has noted (ICJ Statute Commentary, 2012: 617), whenever the General Assembly and the Security Council, exercising their powers under Article 93(2) of the UN Charter accept that an entity, which is not a member of the UN becomes a party to the ICJ Statute, they implicitly determine that said entity is to be considered a State for the purposes of Article 35, any such determination by the competent organs of the UN then being binding upon the Court. Here below the situation concerning access to the Court for advisory proceedings will be addressed in some more detail.

\section{Entities that can provide the Court with relevant information}

The Court has allowed access to the Court to entities that are State-like and accepted as such by the majority of the UN member States. Thus, the Court has allowed access to Palestine and to Kosovo in advisory legal proceedings concerning matters of relevance to both States. While it is debatable whether this can be seen as an implicit recognition of statehood, such participation certainly furthers considerations of fairness in the legal proceedings. The acceptance of the Court's advisory opinion and necessary follow up by the directly concerned parties has been problematic.

In terms of participation in the proceedings, in the Wall case the Court decided that all States entitled to appear before it, as well as Palestine, the United Nations and subsequently, at their request, the League of Arab States and the Organisation of the Islamic Conference, were likely to be able to furnish information on the question in accordance with Article 66(2) and (3), of the Statute. Palestine was allowed to participate in the written and oral submissions to the Court because the General Assembly had granted Palestine a special status of observer and Palestine was co-sponsor of the draft resolution requesting the advisory opinion (Wall, ICJ Reports 2003, p. 429, paras. 2 and 4). Israel objected to Palestine's participation in the proceedings ('Written Statement of the Government of Israel on Jurisdiction and Propriety', 30 January 2004, pp. 13-14, paras. 2.14-2.16).

In the Kosovo's Independence Declaration case, given that the authors of the independence declaration were considered likely to be able to furnish information on the question before it, the Court decided to invite them to make written contributions to the Court (Kosovo's Independence Declaration, ICJ Reports 2008, p. 410, para. 4). As a procedural matter and to avoid any perception of impropriety regarding Kosovo's statehood, the Court distinguished between 'written statements' by UN member States and the 'written contribution' from Kosovo.

\section{The Court's Findings Concerning Admission and Membership in the United Nations}

The issue of membership to the UN is both a political and a legal matter, as the process of acquiring membership into the UN has demonstrated. Given that both the Security Council and the General Assembly need to be agreed, membership in the UN depends largely on acceptance by the permanent members of the Security Council who can veto a positive recommendation and general support by the General Assembly. The ICJ has had to deal with 
this issue in its first and third advisory proceedings, respectively Conditions of Admission of a State to Membership in the United Nations (Article 4 of the Charter) and Competence of the General Assembly for the Admission of a State to the United Nations. The relevant Charter articles were subject to differing interpretations on the part of States.

From the establishment of UN in 1945, some 12 States had unsuccessfully applied for admission. Their applications were rejected by the Security Council in consequence of a veto imposed by one of the permanent members of the Security Council, due to the East-West blocs political divide. The Court interpreted the question posed by the General Assembly as requiring it to advise on:

are the conditions stated in paragraph 1 of Article 4 exhaustive in character in the sense that an affirmative reply would lead to the conclusion that a Member is not legally entitled to make admission dependent on conditions not expressly provided for in that Article, while a negative reply would, on the contrary, authorize a Member to make admission dependent also on other conditions. (Conditions of Admission, ICJ Reports 1949, p. 61)

The Court found that there were five requisite conditions for an applicant legal entity to be admitted to membership in the United Nations, namely:

(1) be a State;

(2) be peace-loving;

(3) accept the obligations of the Charter;

(4) be able to carry out these obligations; and

(5) be willing to do so (Conditions of Admission, ICJ Reports 1949, p. 62).

In interpreting Article 4 of the UN Charter, the Court found that the conditions stated in Article 4(1) must be regarded not merely as the necessary conditions, but also as the conditions which suffice (Conditions of Admission, ICJ Reports 1949, p. 62). The Court clarified that a UN Member State called upon, to pronounce itself by its vote, either in the Security Council or in the General Assembly, on the admission of a State to UN membership, is not juridically entitled to make its consent to the admission dependent on conditions not expressly provided by Article 4(1) (Conditions of Admission, ICJ Reports 1949, p. 65). At the same time, the Court explained that this did not entail en bloc admissions, but that every application for admission should be examined and voted on separately and on its own merits (Conditions of Admission, ICJ Reports 1949, p. 65). A UN member did not have to subject its affirmative vote to the additional condition that other States be admitted to membership in the UN together with that State (Conditions of Admission, ICJ Reports 1949, p. 65). The principled legal position of the Court does not fit well with the political considerations motivating the permanent member States of the UN Security Council, who can eventually veto such admission.

This first advisory opinion of the ICJ did not suffice, as controversies also arouse with regard to the interpretation of Article 4(2) of the UN Charter. In a related advisory opinion, the ICJ decided that it needed to determine solely whether the General Assembly could make 
a decision to admit a State when the Security Council had transmitted no recommendation to it (Competence of Assembly regarding Admission to the United Nations, Advisory Opinion, ICJ Reports 1950, p. 7 (General Assembly Competence)). First, the Court clarified that under Articles 4, 5, and 6, the Security Council co-operates with the General Assembly in matters of admission to membership, of suspension from the exercise of the rights and privileges of membership, and of expulsion from the Organisation (General Assembly Competence, ICJ Reports 1950, p. 9). The ICJ held that admission of a State to UN membership, pursuant to Article 4(2) of the Charter, cannot be effected by a decision of the General Assembly when the Security Council has made no recommendation for admission, by reason of the candidate failing to obtain the requisite majority or of the negative vote of a permanent Member upon a resolution so to recommend (General Assembly Competence, ICJ Reports 1950, p. 10). Jointly, these two advisory opinions have clarified the mechanism of admission of States into the UN.

\section{State Recognition and Self-Determination in the Context of Decolonisation}

The process of achieving statehood follows the exercise of the peoples' right to selfdetermination. While the right to self-determination in the context of decolonisation has become widely accepted, secessionist movements face an uphill struggle vis-à-vis their parent State and an international community of States which is generally wary of such efforts. While it has been the Security Council, as one of the main organs of the UN vested with primary responsibility in the maintenance of international peace and security, that has dealt with issues concerning collective non-recognition (Gowlland-Debbas, 1990), the ICJ has rendered some support to its work by addressing a number of related legal issues which impose a duty on the State concerned, as well as on third States not to recognise any illegal acts. Directly concerned States and third States have an obligation to act within the framework of international law and to refrain from internationally wrongful acts.

\section{Collective Non-Recognition of Internationally Wrongful Acts: The Advisory Opinions on Namibia and Palestine}

This was a case where the Court's findings supported the Security Council's decision regarding the illegal administration by South Africa of Namibia. In its 1971 Advisory Opinion, the Court found that the continued presence of South Africa in Namibia was illegal and that South Africa was under an obligation to withdraw its administration immediately (Legal Consequences for States of the Continued Presence of South Africa in Namibia (South West Africa) notwithstanding Security Council Resolution 276 (1970), ICJ Reports 1971, p. 58, para. 133(1)). Moreover, the ICJ emphasised that all UN member States were under an obligation to recognise the illegality of South Africa's presence in Namibia and the invalidity of its acts on behalf of or concerning Namibia, and to refrain from any acts implying recognition of the legality of, or lending support or assistance to, such presence and administration (Continued Presence of South Africa in Namibia, ICJ Reports 1971, p. 58, para. 133(2)). Finally, the Court even added that it was incumbent upon States which were not UN members to give assistance in the action which had been taken by the UN with regard to Namibia (Continued Presence of South Africa in Namibia, ICJ Reports 1971, p. 58, para. 133(3)). Namibia finally gained its independence in March 1990. 
The case concerning Palestine was about the wall and fences built by Israeli authorities in the Occupied Palestinian Territory. After considering certain fears expressed to it that the route of the wall would prejudge the future frontier between Israel and Palestine, the Court observed that the construction of the wall and its associated régime created a "fait accompli" on the ground that could well become permanent, and hence tantamount to a de facto annexation (Wall, ICJ Reports 2004, p. 184, para. 121). Noting further that the route chosen for the wall gave expression in loco to the illegal measures taken by Israel with regard to Jerusalem and the settlements and entailed further alterations to the demographic composition of the Occupied Palestinian Territory, the Court concluded that the construction of the wall, along with measures taken previously, severely impeded the exercise by the Palestinian people of its right to self-determination and was thus a breach of Israel's obligation to respect that right (Wall, ICJ Reports 2004, p. 184, para. 122).

With regard to legal consequences for Israel, the Court held that Israel is bound to comply with its obligation to respect the right of the Palestinian people to self-determination and its obligations under international humanitarian law and international human rights law (Wall, ICJ Reports 2004, p. 197, para. 149). As regards the legal consequences for other States, the Court held that all States were under an obligation not to recognise the illegal situation resulting from the construction of the wall and not to render aid or assistance in maintaining the situation created by such construction (Wall, ICJ Reports 2004, p. 200, para. 159). The Court further stated that it was for all States, while respecting the United Nations Charter and international law, to see to it that any impediment, resulting from the construction of the wall, to the exercise by the Palestinian people of its right to selfdetermination be brought to an end (Wall, ICJ Reports 2004, p. 200, para. 159). Additionally, the Court has drawn the attention of the General Assembly, to 'the need for the peace efforts to be encouraged with a view to achieving as soon as possible, on the basis of international law, a negotiated solution to the outstanding problems and the establishment of a Palestinian State, existing side by side with Israel and its other neighbours, with peace and security for all in the region' (Wall Advisory Opinion, ICJ Reports 2004, p. 201, para. 162).

These findings can be seen as part of the efforts of the Court to play a constructive role within the UN peace-building framework. Despite the clear language of the Court, the situation on the ground has actually deteriorated with Israeli efforts and determination to legalise the annexation of East Jerusalem which Palestine claims as its capital, and the peace process has been practically defunct for many years, despite significant efforts by the US and France to revive it in 2016-2017.

\section{Decolonisation Process Interrupted: Western Sahara}

A case where the process of decolonisation was interrupted and is still pending is that of Western Sahara. On 13 December 1974, the General Assembly requested an advisory opinion on the following two questions:

I. Was Western Sahara (Rio de Oro and Sakiet El Hamra) at the time of colonization by Spain a territory belonging to no one (terra nullius)? If the answer to the first question is in the negative, 
II. What were the legal ties between this territory and the Kingdom of Morocco and the Mauritanian entity?

In its 1975 Advisory Opinion, the Court found that Western Sahara at the time of colonization by Spain was not a territory belonging to no-one (terra nullius) (Western Sahara, ICJ Reports 1975 , p. 69, para. 163). With regard to Question II, the Court found that the materials and information presented to it showed the existence, at the time of Spanish colonization, of legal ties of allegiance between the Sultan of Morocco and some of the tribes living in the territory of Western Sahara (Western Sahara, ICJ Reports 1975, p. 68, para. 162). They equally showed the existence of rights, including some rights relating to the land, which constituted legal ties between the Mauritanian entity, as understood by the Court, and the territory of Western Sahara (Western Sahara, ICJ Reports 1975, p. 68, para. 162). On the other hand, the Court's conclusion was that the materials and information presented to it did not establish any tie of territorial sovereignty between the territory of Western Sahara and the Kingdom of Morocco or the Mauritanian entity. Thus the Court did not find 'legal ties of such a nature as might affect the application of resolution 1514 (XV) in the decolonization of Western Sahara and, in particular, of the principle of self-determination through the free and genuine expression of the will of the peoples of the Territory' (Western Sahara, ICJ Reports 1975, p. 68, para. 162). Western Sahara remains occupied by Morocco and a long-awaited referendum on independence has still to take place. The issue remains in the agendas of both the General Assembly (UNGA Resolution, UN Doc. A/RES/72/95, 'Question of Western Sahara', 7 December 2017) and the Security Council (UNSC Resolution, UN Doc. S/RES/2414 (2018), 27 April 2018). A mutually acceptable political solution between Morocco and the Sahrawi people represented by POLISARIO remains elusive and the UN peacekeeping mission (MINURSO) remains deployed there.

\section{Declarations of Independence and International Law}

On the basis of a resolution initiated and drafted by Serbia, on 8 October 2008 the General Assembly asked the Court to render an advisory opinion on the following question: "Is the unilateral declaration of independence by the Provisional Institutions of Self-Government of Kosovo in accordance with international law?" (UNGA Resolution 63/3(2008)). The question asked to the Court by the General Assembly was quite a sensitive for Kosovo, seen from a State creation perspective. A finding that the basic document of the emergence of a State is in violation of international law can trigger serious legal and political consequences. What Serbia expected from the Court was a clear condemnation of Kosovo's secession. However, because the question was so narrowly framed, the Court did not consider it 'necessary to address such issues as whether or not the declaration has led to the creation of a State or the status of the acts of recognition' (Kosovo's Declaration of Independence, ICJ Reports 2010, pp. 424, para. 51). Ultimately, the Court concluded that 'the adoption of the declaration of independence of 17 February 2008 did not violate general international law, Security Council resolution 1244(1999) or the Constitutional Framework. Consequently the adoption of that declaration did not violate any applicable rule of international law.' (ICJ Reports 2010, p. 452, para. 122). 
A declaration of independence is practically the birth certificate of a State. The ICJ noted that State practice during the eighteenth, nineteenth and early twentieth centuries 'points clearly to the conclusion that international law contained no prohibition of declarations of independence' (Kosovo's Independence Declaration, ICJ Reports 2010, p. 436, para. 79). In discussing the relevance of the principle of territorial integrity, the Court concluded that 'the scope of the principle of territorial integrity is confined to the sphere of relations between States' (Kosovo's Independence Declaration, ICJ Reports 2010, p. 437, para. 80). Importantly, the ICJ also determined that no general prohibition of declarations of independence could be deduced from Security Council resolutions condemning other declarations of independence, because those declarations of independence had been made in the context of an unlawful use of force or a violation of a jus cogens norm (Kosovo's Independence Declaration, ICJ Reports 2010, pp. 437-438, para. 81). The Court thus concluded that the declaration of independence in respect of Kosovo had not violated general international law (pp. 438-439, para. 84).

The Court then turned to considering whether the declaration of independence was in accordance with Security Council resolution 1244(1999), noting that the object and purpose of that resolution was to establish "a temporary, exceptional legal régime which... superseded the Serbian legal order and which aimed at the stabilization of Kosovo... on an interim basis" (Kosovo's Independence Declaration, ICJ Reports 2010, p. 444, para. 100). The ICJ then examined the identity of the authors of the declaration of independence. An analysis of the content and form of the declaration, and of the context in which it was made, led the Court to conclude that its authors were not the Provisional Institutions of SelfGovernment, but rather "persons who acted together in their capacity as representatives of the people of Kosovo outside the framework of the interim administration" (Kosovo's Independence Declaration, ICJ Reports 2010, pp. 447-448, para. 109). The Court concluded that the declaration of independence did not violate resolution 1244 for two reasons. First, it emphasised the fact that the two instruments "operate on a different level": resolution 1244 was silent on the final status of Kosovo, whereas the declaration of independence was an attempt to finally determine that status (Kosovo's Independence Declaration, ICJ Reports 2010 , p. 449, para. 114). Second, it noted that resolution 1244 imposed only very limited obligations on non-State actors, none of which entailed any prohibition of a declaration of independence (Kosovo's Independence Declaration, ICJ Reports 2010, pp. 451-452, paras. 118-119). Finally, in view of its conclusion that the declaration of independence did not emanate from the Provisional Institutions of Self-Government of Kosovo, the Court held that its authors were not bound by the Constitutional Framework established under resolution 1244 , and thus that the declaration of independence did not violate that framework (Kosovo's Independence Declaration, ICJ Reports 2010, p. 452, para. 121). These findings of the Court have provided some context to the interaction between domestic law and international law, the relationship between the General Assembly and the Security Council concerning international administration of territory and maintenance of peace, and potential legal consequences for declarations of independence of new States.

In September 2010, a few months after the rendering of the advisory opinion, the General Assembly adopted a very brief resolution, essentially taking note of the ICJ decision and welcoming the readiness of the European Union to facilitate a process of dialogue 
between the parties (UNGA Resolution 64/298 (2010)). Considering that by then about 70 UN member States had already recognised Kosovo, this was a missed opportunity for Kosovo and countries that had recognised its independence to use the favourable advisory opinion in pushing for increased international recognition. As it is often the case, the balanced decision of the Court allowed both sides to claim victory. Kosovo, pointing to the dispositif of the advisory opinion, claimed that its declaration of independence was valid under international law. Serbia, ironically pointing to the question not asked in the advisory opinion, claimed that the Court had not recognised Kosovo's statehood.

More generally, as Marc Weller has noted (2015: 215), the Kosovo advisory opinion has not led to an avalanche of unilateral declarations of independence the world over. Anne Peters has pointed out (2015: 312) that the political intention of the States highlighting the uniqueness of Kosovo was to send a message to Catalans, Scots, Basques, Corsicans, and Quebecois that they would not be allowed to rely on the Kosovo case to justify their secession. Though closely related, international law and politics live separate lives. Thus, while legally opposed to Kosovo's independence, Russia has not hesitated to use the Kosovo 'precedent' to justify its aggression against Georgia in August 2008 and subsequent recognition of South Ossetia and Abkhazia, and its intervention in Ukraine in 2014 and the unlawful annexation of Crimea. An EU facilitated dialogue between Serbia and Kosovo continues and several bilateral agreements have been reached, although their implementation has lagged behind and some of them have attracted considerable domestic controversies.

\section{Concluding Remarks}

The UN Charter and the ICJ Statute try to ensure the broadest possible access to the jurisdiction of the Court for both member and non-member States to the UN. A resolution of the Security Council has established an opt-in possibility for UN non-member States. Understandably, the process of State creation and State recognition, including the exercise of State attributes through membership into international and regional organizations and access to international legal proceedings, is bound to be controversial, as demonstrated by the case law of the ICJ. The contribution of the ICJ to the process of State creation and recognition has been important in several respects. First, the ICJ has helped in clarifying the criteria for admission to UN membership and the role of the General Assembly and the Security Council therein. Second, the Court has advised the General Assembly and the Security Council with regard to the emergence of new States through the process of decolonisation. Third, and more recently, the Court has clarified legal aspects of declarations of independence under international law. Pending cases before the Court which relate to the creation of States and related issues are those of Legal Consequences of the Separation of the Chagos Archipelago from Mauritius in 1965 (Request for Advisory Opinion) and the Relocation of the United States Embassy to Jerusalem (Palestine v. United States of America).

Perhaps the main direct contribution of the Court to the issue of recognition of States are its two advisory opinions on the criteria for admission to the UN and General Assembly competences. The Court has interpreted Article 4 of the UN Charter as including all necessary criteria for assessment of a State for membership in the UN, rejecting in this manner any claims for absolute or arbitrary discretion. With regard to General Assembly competences, the Court has found that the General Assembly cannot proceed in the absence 
of a favourable recommendation by the Security Council. Conditions for access to States in contentious cases and advisory proceedings before the Court are based on the general principles of fairness and equality of parties to legal proceedings. The ICJ seems to have broadened the possibility of participation in legal proceedings of State-like entities, among others by having accepted two legal entities to join the advisory proceedings concerning them, namely Palestine and Kosovo.

From the perspective of the law of international responsibility, the main gist of ICJ's contribution refers to threefold obligations on the part of concerned States, third States, and the main UN organs not to recognise illegal acts which hinder a peoples' right to selfdetermination, not to render support to the maintenance of an illegal situation, and to their residual duty to ensure that a just and durable solution is found for long-standing conflicts, including those concerning the Occupied Palestinian Territory and the Western Sahara. If the ICJ were to assume a regular fact-finding function concerning the process of State creation, cases of premature or tardy recognition could be reduced to a minimum and recognition as a political act could be made more or less independent of the game of power politics, a step essential for the consolidation of the international society (Alexandrowicz, 2017: 383). States are content with the discretionary power concerning State recognition, however, and there does not seem to be enough political will to make the Court a central actor for this purpose. Nevertheless, the ICJ can still contribute to such important processes as State creation and recognition in a piecemeal fashion.

\section{References}

\section{Legal instruments}

Convention on the Rights and Duties of States, 26 December 1933, 165 LNTS 19.

Security Council Resolution 9(1946), 'Admission of States not Parties to the Statute of the Court', 15 October 1946.

Security Council Resolution 272(1969), 23 October 1969.

General Assembly Resolution 264(III), 8 October 1948.

General Assembly Resolution 2520(XXIV), 4 December 1969.

General Assembly Resolution A/ES-10/L.16 (2003), 'Illegal Israeli actions in Occupied East Jerusalem and the rest of the Occupied Palestinian Territory', 3 December 2003.

UNGA Resolution 63/3(2008), 'Request for an advisory opinion of the International Court of Justice on whether the unilateral declaration of independence of Kosovo is in accordance with international law', 8 October 2008.

UNGA Resolution 64/298 (2010), 'Request for an advisory opinion of the International Court of Justice on whether the unilateral declaration of independence of Kosovo is in accordance with international law', 13 October 2010.

\section{Case law}

Conditions of Admission of a State to Membership in the United Nations (Article 4 of the Charter), ICJ Reports 1948, p. 57.

Competence of Assembly regarding admission to the United Nations, ICJ Reports 1950, p. 4. Gabčikovo-Nagymaros Project (Hungary/Slovakia), ICJ Reports 1997, p. 7. 
Legal Consequences for States of the Continued Presence of South Africa in Namibia (South West Africa) notwithstanding Security Council Resolution 276 (1970), ICJ Reports 1971, p. 16.

Application of the Convention on the Prevention and Punishment of the Crime of Genocide (Bosnia and Herzegovina v. Serbia and Montenegro), ICJ Reports 1996, p. 595.

Legal Consequences of the Construction of a Wall in the Occupied Palestinian Territory, ICJ Reports 2003, p. 428.

Legal Consequences of the Construction of a Wall in the Occupied Palestinian Territory, ICJ Reports 2004, p. 136.

Accordance with International Law of the Unilateral Declaration of Independence by the Provisional Institutions of Self-Government of Kosovo, ICJ Reports 2008, p. 409.

Accordance with International Law of the Unilateral Declaration of Independence by the Provisional Institutions of Self-Government of Kosovo, ICJ Reports 2010, p. 403.

Relocation of the United States Embassy to Jerusalem (Palestine v. United States of America), Application of 28 September 2018.

\section{Literature}

Alexandrowicz, C. H. (2017) 'The Quasi-Judicial Function in Recognition of States and Governments (1952)', in Alexandrowicz, C.H., Armitage, D., and Pitts J. (eds) The Law of Nations in Global History, Oxford: Oxford University Press.

Aljaghoub, M. (2006) The Advisory Function of the International Court of Justice 19462005, Heidelberg: Springer.

Cassese, A. (1995) Self-Determination of Peoples: A Legal Reappraisal, Cambridge: Cambridge University Press.

Crawford, J. (2006) The Creation of States in International Law, second edition, Oxford: Oxford University Press.

Dugard, J. (1987) Recognition and the United Nations, Cambridge: Grotius Publications Limited.

Fabry, M. (2010) Recognizing States: International Society and the Establishment of New States Since 1776, Oxford: Oxford University Press.

Gowlland-Debbas, V. (1990) Collective Responses to Illegal Acts in International Law: United Nations Action in the Question of Southern Rhodesia, Leiden: Nijhoff.

Hernández, G. (2011) 'Non-State Actors from the Perspective of the International Court of Justice', in d'Aspremont J. (ed) Participants in the International Legal System: Multiple Perspectives on Non-State Actors in International Law, London and New York: Routledge.

Hernández, G. (2014) The International Court of Justice and the Judicial Function, Oxford: Oxford University Press.

Kolb, R. (2013) The International Court of Justice, Oxford: Hart Publishing.

Lauterpacht, H. (1947) Recognition in International Law, Cambridge: Cambridge University Press.

Orakhelashvili, A. (2015) 'The Dynamics of Statehood in the Practice of International and English Courts', in Chinkin C. and Baetens F. (eds) Sovereignty, Statehood and State Responsibility: Essays in Honour of James Crawford, Cambridge University Press. 
Peters, A. (2015) 'Has the Advisory Opinion's Finding that Kosovo's Declaration of Independence was not Contrary to International Law Set an Unfortunate Precedent?' in Milanović, M and Wood, M. (eds) The Law and Politics of the Kosovo Advisory Opinion, Oxford: Oxford University Press.

Riziki Majinge, C. (2012) 'Emergence of New States in Africa and Territorial Dispute Resolution: The Role of the International Court of Justice', Melbourne Journal of International Law 13: 462-504.

Rosenne, S. (1949) 'Recognition of States by the United Nations', British Yearbook of International Law 26: 437-447.

Rosenne, S. (2006) The Law and Practice of the International Court, 1920-2005, 4th edition, Leiden: Martinus Nijhoff Publishers.

Rosenne, S. (2010) 'Capacity to Litigate in the International Court of Justice: Reflections on Yugoslavia in the Court', British Yearbook of International Law 80(1): 217-243.

Schulte, C. (2004) Compliance with Decisions of the International Court of Justice, Oxford: Oxford University Press.

Shaw M. (2016) Rosenne's Law and Practice of the International Court, 1920-2015, 5th edition, The Hague: Brill Nijhoff.

Summers, J. (2013) Peoples and International Law, 2nd edition (Martinus Nijhoff Publishers. Talmon, S. (2000) Recognition in International Law: A Bibliography, The Hague, London, Boston: Martinus Nijhoff Publishers.

Tams, C. and Sloan J. (eds) (2013) The Development of International Law by the International Court of Justice, Oxford: Oxford University Press.

The International Court of Justice (2014) The International Court of Justice Handbook, 6th edition.

Thirlway, H. (2016) The International Court of Justice, Oxford: Oxford University Press.

Weller, M. (2015), 'The Sounds of Silence: Making Sense of the Supposed Gaps in the Kosovo Opinion' in Milanović, M and Wood, M. (eds) The Law and Politics of the Kosovo Advisory Opinion, Oxford: Oxford University Press.

Zimmermann, A., Tomuschat C., Oellers-Frahm K., and Tams C. (eds) (2012) The Statute of the International Court of Justice: A Commentary, 2nd edition, Oxford: Oxford University Press, (ICJ Statute Commentary).

Zyberi, G. (2008) The Humanitarian Face of the International Court of Justice: Its Contribution to Interpreting and Developing International Human Rights and Humanitarian Law Rules and Principles, Antwerpen-Oxford-Portland: Intersentia.

Zyberi, G. (2009) 'Self-Determination through the Lens of the International Court of Justice', Netherlands International Law Review 56(3): 429-453.

\section{Websites and case law}

www.icj-cij.org/en/states-entitled-to-appear

www.icj-cij.org/en/case/3 (Conditions of Admission)

www.icj-cij.org/en/case/9 (Competence of the General Assembly)

www.icj-cij.org/en/case/53 (Continued Presence of South Africa in Namibia)

www.icj-cij.org/en/case/61 (Western Sahara)

www.icj-cij.org/en/case/91 (Application of the Genocide Convention) 
www.icj-cij.org/en/case/92 (Gabčíkovo-Nagymaros Project)

www.icj-cij.org/en/case/131 (Wall)

www.icj-cij.org/en/case/141 (Kosovo's Independence Declaration)

www.icj-cij.org/en/case/169 (Separation of the Chagos Archipelago from Mauritius)

www.icj-cij.org/en/case/176 (Relocation of the US Embassy to Jerusalem)

https://pca-cpa.org/en/news/new-pca-member-state-palestine

https://pca-cpa.org/en/news/new-pca-member-state-kosovo

www.icc-cpi.int/palestine 